\title{
THE APPLICATION OF COOPERATIVE LEARNING MODEL IN PEDAGOGIC COURSE
}

\section{PENERAPAN MODEL PEMBELAJARAN KOOPERATIF DALAM MATA KULIAH PEDAGOGIK}

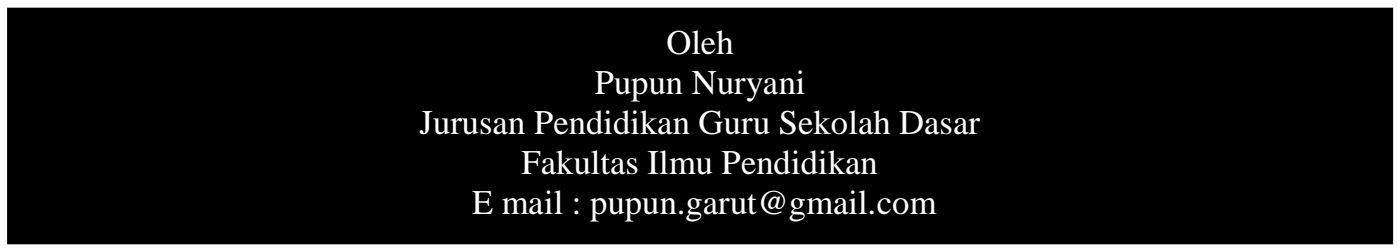

Abstract. Today the challenges of employment is more toward teamwork. Given the growing importance of cooperative interactions in employment, this should be anticipated by the education world, one of which through classroom instruction strategies. This study aimed to describe the initial condition of the characteristic of PGSD students' ability inPedagogic course, to depic the application of cooperative learning in Pedagogic course, and to know the strengths and weaknesses of cooperative learning in Pedagogic course. This used qualitative approach with descriptive analysis method. The results showed that the initial condition of the characteristic of PGSD students' ability in in Pedagogic coursebasically has a good enough quality. It was also found that. theapplication of cooperative learning is more preferable for students than lecturing method. The results conclude that the application of cooperative learning in Pedagogic course can improve the ability of students in the learning process.

Keywords : Cooperative Learning Model, Pedagogic course,

Abstrak. Dewasa ini tantangan lapangan pekerjaan lebih banyak berorientasi pada kerjasama tim. Mengingat semakin pentingnya interaksi kooperatif dalam lapangan pekerjaan, maka hal ini harus diantisipasi oleh dunia pendidikan salah satunya melalui strategi pembelajaran kelas. Penelitian ini bertujuan untuk mendeskripsikan kondisi awal karakteristik kemampuan mahasiswa PGSD pada mata kuliah pedagogik; mendeskripsikan penerapan model pembelajaran kooperatif pada mata kuliah pedagogik; mengetahui kelebihan dan kelemahan model pembelajaran kooperatif pada mata kuliah pedagogic. Penelitian ini menggunakan metode deskriptif analisis. Sedangkan pendekatan yang digunakan pada penelitian ini adalah pendekatan kualitatif.. Hasil penelitian menunjukan kondisi awal karakteristik kemampuan mahasiswa PGSD pada mata kuliah pedagogik pada dasarnya memiliki kualitas yang cukup baik. Hasil penelitian juga menunjukkan bahwa penerapan model pembelajaran kooperatif dalam mata kuliah pedagogik lebih disukai mahasiswa dibandingkan dengan menggunakan metode ceramah. Simpulan hasil penelitian, penerapan model pembelajaran kooperatif pada mata kuliah pedagogik dapat meningkatkan kemampuan mahasiswa dalam proses pembelajaran.

Kata Kunci : model pembelajaran kooperatif, mata kuliah Pedagogik

\section{A. PENDAHULUAN}

Mahasiswa memerlukan pengalaman untuk menghadapi tantangan bidang pekerjaan di masa mendatang. Dewasa ini tantangan lapangan pekerjaan lebih banyak berorientasi pada kerjasama tim. Kerjasama antara kelompok dan berkomunikasi merupakan suatu

keterampilan yang perlu dimiliki agar tercipta suasana kerja yang baik. Mengingat semakin pentingnya interaksi kooperatif dalam lapangan pekerjaan, maka hal ini harus diantisipasi oleh dunia 
pendidikan salah satunya melalui strategi pembelajaran kelas.

Pada saat ini dikenal tiga macam strategi pembelajaran, yaitu pembelajaran individual, kompetitif dan pembelajaran kooperatif. (Lie, 2000). Dalam pembelajaran individual setiap mahasiswa belajar berdasarkan pada kecepatan yang sesuai dengan kemampuan mereka sendiri. Pendidik hanya memberikan sedikit monitor pada proses pembelajaran. Mahasiswa tidak bersaing dengan temantemannya melainkan dengan dirinya sendiri. Asumsi dari model pengajaran individual ini adalah bahwa mahasiswa memiliki karakteristik sendiri. Oleh karena itu mereka diberi kesempatan khusus untuk mengembangkan potensinya semaksimal mungkin. Kelemahan model pembelajaran ini adalah mahalnya biaya yang harus dikeluarkan untuk menyediakan fasilitasfasilitas seperti modul atau paket-paket dan learning centres. Selain itu pembelajaran individual akan menghasilkan mahasiswa yang individualistik yang nantinya dapat menyulitkan mereka dalam hidup bermasyarakat, (Nur, 1994 dalam Lie, 2000).

Model pembelajaran yang pada saat ini dikembangkan dalam sistem pendidikan adalah pembelajaran kooperatif. Model pembelajaran kooperatif menekankan pada kerjasama kelompok kecil yang terdiri dari 4 - 6 anggota kelompok (Slavin, 1985). Pengaturan tugas untuk setiap anggota diatur sedemikan rupa sehingga setiap anggota kelompok bertanggung jawab terhadap tugas individualnya sebelum mereka mengkontribusikan pemikirannya terhadap kelompoknya. Dengan demikian melalui pembelajaran kooperatif akan terjadi peningkatan ketelitian dalam mengambil pertimbangan termasuk pertimbangan dalam menggunakan keterampilan ilmiah (Slavin, 1985). Lebih jauh Johnson \& Johnson (2001) memberikan pandangan bahwa pembelajaran kooperatif merupakan strategi yang menggunakan kelompok kecil. Setiap kelompok dalam pembelajaran kooperatif terdiri dari mahasiswa yang berasal dari tingkat kemampuan yang berbeda. Dalam pembelajaran kooperatif setiap anggota kelompok tidak hanya bertanggung jawab pada tugasnya sendiri, tetapi juga membantu proses belajar teman sekelompoknya. Dengan demikian ada saling ketergantungan positif diantara anggota kelompoknya. Karena adanya saling ketergantungan antar teman dalam kelompok, maka akan terjadi interaksi kooperatif dalam pembelajaran yang menghasilkan pengetahuan yang diperoleh mahasiswa dari temannya sebagai hasil diskusi kelompok. Newman dan Holzman (dalam Hariyanto, 2000) mengemukakan bahwa pengetahuan dari hasil pembelajaran kooperatif merupakan hasil 
belajar secara komprehensif yang diperoleh kelompok.

Model pembelajaran kooperatif dapat membantu pengorganisasian terhadap tugas dan tanggung jawab kelompok maupun individu untuk mencapai kepentingan kelompok. Hal ini disebabkan karena dalam pembelajaran kooperatif tahapan kegiatan disusun secara berstruktur. Penyusunan tahapan atau langkah kegiatan ini bertujuan untuk menciptakan suasana belajar yang lebih bermakna serta menumbuhkan partisipasi aktif mahasiswa. Dengan demikian pada akhir pembelajaran ditanamankan perasaan bangga pada diri mahasiswa terhadap hasil temuannya sendiri. Mata kuliah pedagogik merupakan salah satu mata kuliah wajib yang harus diikuti oleh mahasiswa program studi PGSD. Pada mata kuliah ini dibahas asumsi-asumsi pendidikan yang meliputi konsep pedagogik, manusia dan pendidikan, pengertian pendidikan, pendidikan sebagai ilmu dan seni, landasan filosofis pendidikan, landasan psikologis pendidikan, landasan sosiologis dan antropologis pendidikan, landasan historis pendidikan dan landasan yuridis pendidikan dan sebagai bahan renungan dan pijakan dalam melaksanakan praktek dan studi pendidikan. Dengan memahami hal tersebut para mahasiswa diharapkan mampu menggali permasalahan sebagai bahan pemikiran dan renungan yang dapat diimplementasikannya yang selanjutnya bisa dijadikan bahan penelitian.

Data hasil belajar mahasiswa selama tiga tahun terakhir ini menunjukkan bahwa prestasi belajar mahasiswa terhadap penguasaan materi perkuliahan pedagogik dirasakan belum sesuai dengan harapan. Ditambah lagi kemampuan para guru SD yang sudah sarjana pun tidak menunjukkan kemampuan melaksanakan model pembelajaran kooperatif yang baik, padahal harapannya adalah kemampuan melaksanakaan model pembelajaran kooperatif guru SD bisa sama dengan kemampuan melaksanakan model pembelajaran kooperatif guru sekolah lanjutan.

Sehubungan dengan hal tersebut, pengelolaan dan peningkatan kualitas proses perkuliahan pedagogik sangatlah diperlukan guna mencapai tujuan perkuliahan ini sebagaimana dikemukakan sebelumnya. Untuk itu salah satu cara yang digunakan adalah penerapan model pembelajaran kooperatif dalam mata kuliah pedagogik di Prodi PGSD. Permasalahannya adalah sejauh mana cara ini dapat meningkatkan kualitas pembelajaran dan mutu hasil belajar mahasiswa pada mata kuliah pedagogik.

Dengan demikian melalui pembelajaran kooperatif akan terjadi peningkatan ketelitian dalam mengambil pertimbangan termasuk pertimbangan dalam menggunakan keterampilan ilmiah 
(Slavin, 1985). Lebih jauh Johnson \& Johnson (2001) memberikan pandangan bahwa pembelajaran kooperatif merupakan strategi yang menggunakan kelompok kecil. Setiap kelompok dalam pembelajaran kooperatif terdiri dari mahasiswa yang berasal dari tingkatanya kemampuan yang berbeda. Dalam pembelajaran kooperatif setiap anggota kelompok tidak hanya bertanggung jawab pada tugasnya sendiri, tetapi juga membantu proses belajar teman sekelompoknya. Dengan demikian ada saling ketergantungan positif diantara anggota kelompoknya. Karena adanya saling ketergantungan antar teman dalam kelompok, maka akan terjadi interaksi kooperatif dalam pembelajaran yang menghasilkan pengetahuan yang diperoleh mahasiswa dari temannya sebagai hasil diskusi kelompok.

Berdasarkan latar belakang masalah di atas, teridentifikasi beberapa pertanyaan penelitian sebagai berikut:

1. Bagaimana kondisi awal karakteristik kemampuan mahasiswa PGSD pada mata kuliah pedagogik?

2. Bagaimana penerapan model pembelajaran kooperatif pada mata kuliah pedagogik?

3. Bagaimana kelebihan dan kelemahan model pembelajaran kooperatif pada mata kuliah pedagogik?

Secara umum, tujuan penelitian ini adalah memperoleh gambaran yang jelas tentang penerapan model pembelajaran kooperatif pada mata kuliah pedagogik sedangkan secara khusus, tujuan yang hendak dicapai dari Penelitian ini sebagai berikut.

1. Mendeskripsikan kondisi awal karakteristik kemampuan mahasiswa PGSD pada mata kuliah pedagogik

2. Mendeskripsikan penerapan model pembelajaran kooperatif pada mata kuliah pedagogik

3. Mengetahui kelebihan dan kelemahan model pembelajaran kooperatif pada mata kuliah pedagogik

Landasan konsepsi digunakan sebagai dasar berpijak dalam mengembangkan pemikiran lebih lanjut. Selain itu, landasan teori juga digunakan sebagai alat untuk mengamati suatu fenomena. Selanjutnya, landasan teori dapat digunakan pula sebagai alat dalam melakukan analisis penelitian. Adapun teori yang melandasi dalam penelitian ini adalah :

1. Konsep Dasar Pembelajaran Cooperative Learning

Metode pembelajaran cooperative learning merupakan salah satu metode pembelajaran yang telah lama digunakan dalam proses kegiatan belajar mengajar. Pada umumnya metode pembelajaran tersebut lebih dikenal sebagai metode pembelajaran gotong royong atau model kerja kelompok. Namun para ahli memberikan penekanan yang 
Edutech, Tahun 14, Vol.1, No.1, Februari 2015

khusus pada metode cooperative learning ini bila dibandingkan dengan metode kerja kelompok yang biasanya sering para pendidik mempraktekkannya di kelas.

Model pembelajaran cooperative learning ini beranjak dari dasar pemikiran "getting better together", yang menekankan pada pemberian kesempatan belajar yang lebih luas dan suasana yang kondusif kepada mahasiswa untuk memperoleh, dan mengembangkan pengetahuan, sikap, nilai serta keterampilan keterampilan sosial yang bermanfaat bagi kehidupannya di masyarakat. Melalui cooperative learning, mahasiswa bukan hanya belajar dan menerima apa yang disajikan oleh dosen dalam proses belajar mengajar, melainkan bisa juga belajar dari mahasiswa lainnya, dan sekaligus mempunyai kesempatan untuk membelajarkan mahasiswa yang lainnya. Proses pembelajaran dengan cooperative learning ini mampu merangsang dan menggugah potensi mahasiswa secara optimal dalam suasana belajar pada kelompokkelompok kecil yang terdiri dari 2 sampai 6 orang mahasiswa (Stahl, 1994). Pada saat mahasiswa belajar dalam kelompok akan berkembang suasana belajar yang terbuka dalam dimensi kesejawatan, karena pada saat itu akan terjadi proses belajar kolaboratif dalam hubungan pribadi yang saling membutuhkan . Pada saat itu juga mahasiswa yang belajar dalam kelompok kecil akan tumbuh dan berkembang pola belajar tutor sebaya (peer group) dan belajar secara bekerjasama (cooperative). (Kagan, 2013)

2. Karakteristik Pembelajaran Kooperatif

Metode cooperative learning ini disebut juga sebagai pembelajaran gotong royong, belajar bekerja sama tetapi tidak sama dengan kerja kelompok biasa yang dilakukan tanpa rancangan tertentu yang dibuat oleh dosen. Dalam cooperative learning, setiap mahasiswa dituntut untuk bekerja dalam kelompok melalui rancangan-rancangan tertentu yang sudah dipersiapkan oleh dosen, sehingga seluruh mahasiswa harus bekerja aktif.

Model pembelajaran kooperatif dikembangkan berpijak pada beberapa pendekatan yang diasumsikan mampu meningkatkan proses dan hasil belajar mahasiswa. Pendekatan yang dimaksud adalah belajar aktif, konstruktivistik, dan kooperatif. Beberapa pendekatan tersebut diintegrasikan dimaksudkan untuk menghasilkan suatu model pembelajaran yang memungkinkan 
Edutech, Tahun 14, Vol.1, No.1, Februari 2015

mahasiswa dapat mengembangkan potensinya secara optimal. Belajar aktif, ditunjukkan dengan adanya keterlibatan intelektual dan emosional yang tinggi dalam proses belajar, tidak sekedar fisik semaya. Mahasiswa diberi kesempatan untuk berdiskusi, mengemukakan pendapat dan idenya, melakukan eksplorasi terhadap materi yang sedang dipelajari serta menafsirkan hasilnya secara bersama-sama di dalam kelompok. Mahasiswa dibebaskan untuk mencari berbagai sumber belajar yang relevan. Kegiatan demikian memungkinkan mahasiswa berinteraksi aktif dengan lingkungan dan kelompoknya, sebagai media untuk mengembangkan pengetahuannya.

Pendekatan konstruktivistik dalam model pembelajaran kooperatif dapat mendorong mahasiswa untuk mampu membangun pengetahuannya secara bersama-sama di dalam kelompok. Mereka didorong untuk menemukan dan mengkonstruksi materi yang sedang dipelajari melalui diskusi, observasi atau percobaan. Mahasiswa menafsirkan bersamasama apa yang mereka temukan atau mereka bahas. Dengan cara demikian, materi pelajaran dapat dibangun bersama dan bukan sebagai transfer dari dosen. Pengetahuan dibentuk bersama berdasarkan pengalaman serta interaksinya dengan lingkungan di dalam kelompok belajar, sehingga terjadi saling memperkaya diantara anggota kelompok. Ini berarti, mahasiswa didorong untuk membangun makna dari pengalamannya, sehingga pemahaman terhadap fenomena yang sedang dipelajari meningkat. Mereka didorong untuk memunculkan berbagai dusut pandang terhadap materi atau masalah yang sama, untuk kemudian membangun sudut pandang atau mengkonstruksi pengetahuannya secara bersama pula. Hal ini merupakan realisasi dari hakikat konstruksivisme dalam pembelajaran. Menurut Lie (2004:31) terdapat lima unsur dalam metode cooperative learning yang membedakannya dengan kerja kelompok, yaitu: 1) Saling ketergantungan positif, 2) tanggung jawab perseorangan, 3) tatap muka, 4) komunikasi antar anggota, dan 5) evaluasi proses kelompok.

\section{Konsep Pedagogik}

Pedagogik merupakan ilmu yang mengkaji bagaimana membimbing anak, bagaimana sebaiknya pendidik berhadapan dengan anak didik, apa tugas pendidik dalam mendidik anak, apa yang menjadi tujuan mendidik 
Edutech, Tahun 14, Vol.1, No.1, Februari 2015

anak. Dalam bagian ini akan dibagai pengertian pedagogik, pendidikan dalam arti khusus dan arti luas. Pendidikan mengandung tiga aspek, yaitu mendidik, mengajar dan melatih, dan di bawah ini akan diuraikan perbedaan antara ketiga aspek tersebut, yaitu perbedaan antara mendidik, mengajar dan melatih.

Pedagogik merupakan kajian pendidikan. Secara etimologi berasal dari kata Yunani "paedos", yang berarti anak laki-laki dan "agogos" artinya mengantar, membimbing. Jadi pedagogik secara harfiah berarti pembantu anak laki-laki pada jaman Yunani kuno, yang pekerjaannya mengantarkan anak majikannya ke sekolah. Kemudian secara kiasan, pedagogik ialah seorang ahli, yang membimbing anak ke arah tujuan hidup tertentu. Menurut Prof. Dr. J. Hoogveld (dalam Hopskin, 1993) pedagogik adalah ilmu yang mempelajari masalah membimbing anak ke arah tujuan tertentu, yaitu supaya kelak ia "mampu secara mandiri menyelesaikan tugas hidupnya”. Jadi pedagogik adalah Ilmu Pendidikan Anak. Langveld (1980 dalam Suryo, 1990) membedakan istilah "pedagogik" dengan istilah "pedagogi”. Pedagogik diartikan dengan ilmu pendidikan, lebih menitikberatkan kepada pemikiran, perenungan tentang pendidikan. Suatu pemikiran bagaimana kita membimbing anak, mendidik anak. Sedangkan istilah pedagogi berarti pendidikan, yang lebih menekankan kepada praktek, menyangkut kegiatan mendidik, kegiatan membimbing anak. Pedagogik merupakan suatu teori yang secara teliti, kritis dan objektif mengembangkan konsep-konsepnya mengenai hakekat manusia, hakekat anak, hakekat tujuan pendidikan serta hakekat proses pendidikan.

\section{B. HASIL DAN PEMBAHASAN}

1. Kondisi Objektif Tempat Penelitian

Penelitian tindakan kelas ini dilaksanakan di jurusan pedagogik, fakultas ilmu pendidikan, UPI Bandung, yaitu universitas tempat peneliti melaksanakan tugas sebagai tenaga pengajar. Lokasi universitas tersebut terletak di Jln. Setiabudi No.229 Bandung. Universitas ini letaknya cukup strategis karena mudah dilalui oleh angkutan umum serta berada di sekitar lingkungan pertokoan dan beberapa hotel di Bandung.

Jurusan pedagogik ini memiliki fasilitas penunjang kegiatan belajar yang berupa ruang kelas, ruang perpustakaan, ruang lab komputer dan internet, ruang kantor jurusan, ruang 
Edutech, Tahun 14, Vol.1, No.1, Februari 2015

dosen, ruang administrasi, ruang serbaguna, serta toilet dosen dan mahasiswa.

a. Kondisi Dosen

Berdasarkan data yang diperoleh dari pihak jurusan, dosen yang mengajar di jurusan pedagogik berasal dari lulusan berbagai perguruan tinggi seperti UPI Bandung dan universitas lainnya. Adapun tingkat pendidikan para dosen tersebut adalah Magister, Doktor dan Profesor.

Dosen mata kuliah pedagogik di jurusan pedagogik memiliki tingkat pendidikan adalah jenjang S2 dan S3. Berdasarkan latar belakangnya, dosen-dosen tersebut merupakan dosen yang sudah berpengalaman karena telah mengajar dalam waktu kurang lebih 15 tahun. Bahkan, mereka telah memiliki pengalaman mengajar sebagai dosen luar biasa semenjak mereka duduk di bangku perkuliahan. Selain mengajar di UPI, dosen-dosen tersebut ada pula yang mengajar di pergurun tinggi lainnya. Dengan demikian dapat dikatakan bahwa dosen mata kuliah pedagogik di jurusan pedagogik adalah dosen yang sudah berpengalaman jika dilihat dari lamanya usia mengajar dan medan mengajar yang dihadapinya.

b. Kondisi Mahasiswa

Kelas tempat peneliti melakukan observasi adalah kelas pada program studi PGSD angkatan 2011 yang terletak di lantai satu. Ruangan kelas tersebut cukup luas untuk menampung 44 orang mahasiswa, ventilasi udara cukup bagus dan pencahayaan kelas juga bagus.

Berdasarkan hasil pengamatan, sesungguhnya cukup kondusif. karena ruangan kelas merupakan faktor penunjang terlaksananya kegiatan pembelajaran yang tertib dan nyaman. Jumlah mahasiswa jurusan pedagogik pada program studi PGSD untuk tahun ajaran 2011/2012 adalah 44 (empat puluh empat) orang, yang terdiri dari 10 (sepuluh) orang laki-laki dan 34 (tiga puluh empat) orang perempuan. Dari 44 (empat puluh empat) orang mahasiswa tersebut, $78 \%$ berasal dari sekolah menengah negeri serta sisanya sebanyak $22 \%$ berasal dari sekolah menengah swasta dan Madrasah Aliyah. Rata-rata mahasiswa berasal dari luar kota Bandung. 
2. Kondisi Awal Karakteristik Kemampuan Mahasiswa PGSD Pada Mata Kuliah Pedagogik

Berdasarkan hasil pengamatan dan pengalaman peneliti selama mengajar mata kuliah pedagogik, mahasiswa di kelas program studi PGSD angkatan 2011 ini pada dasarnya memiliki kualitas yang cukup baik dalam setiap mata kuliah, tetapi secara umum memiliki kesan cukup negatif terhadap beberapa mata kuliah. Pada awal masuk di semester pertama dan kedua saat pembelajaran pedagogik berlangsung, peneliti menyaksikan bahwa suasana belajar kurang menyenangkan, motivasi belajar mahasiswa rendah, dan rata-rata mahasiswa masih pasif, kurang aktif dalam menyimak ataupun bertanya jawab saat proses pembelajaran berlangsung.

Dalam penelitian awal, peneliti menemukan kondisi tersebut ditimbulkan oleh diri mereka sendiri. Rata-rata mereka berasal dari sekolah menengah umum, dan kebanyakan dari daerah. Kondisi awal kemampuan mahasiswa terhadap mata kuliah pedagogik kurang begitu menarik buat mereka. Karena tidak semua mahasiswa PGSD diangkatan 2011 memiliki minat masuk ke PGSD awalnya. Ada mahasiswa yang masuk ke PGSD sebagai pilihan kedua, namun tidak sedikit juga mahasiswa yang memang dari awal masuk ke UPI itu memilih PGSD sebagai pilihan utama dan pertama. Sehingga dampaknya diawal masa perkuliahan mereka mengalami kebingungan dalam menerima setiap materi mata kuliah, salah satunya adalah mata kuliah pedagogic. Hal ini lebih disebabkan karena mahasiswa belum beradaptasi dengan kondisi lingkungan di kampus. Kondisi tersebut wajar dan bisa dimaklumi, karena saat mereka duduk dibangku sekolah menengah mereka tidak pernah mendapatkan materi tentang pedagogic.

Selain itu, adanya rasa jenuh dan bosan pada diri mahasiswa akibat metode mengajar yang digunakan dosen pada mata kuliah pedagogic pun menjadi salah sebab kurangnya minat mahasiswa untuk aktif dalam perkuliahan. Dalam hal ini, dosen menyajikan pembelajaran dengan menyampaikan tumpukan informasi yang berupa fakta dan cenderung mengabaikan materi yang berhubungan dengan masalah-masalah yang dekat 
Edutech, Tahun 14, Vol.1, No.1, Februari 2015

dengan kehidupan mahasiswa.

Selain itu, beberapa dosen masih menempatkan diri sebagai pusat kegiatan belajar dan cenderung tidak banyak memberikan kesempatan kepada mahasiswa untuk terlibat aktif dalam kegiatan belajar mengajar. Di samping itu, dosen juga masih jarang memberikan kesempatan kepada mahasiswa untuk menyampaikan atau merefleksikan gagasannya terhadap orang lain, sehingga dalam hal ini dosen tidak menjadi fasilitator yang dapat mendorong mahasiswa untuk mengembangkan pemahaman mengenai materi pedagogik yang dipelajarinya.

Disamping kondisi mahasiswa yang telah disebutkan di atas, tidak sedikit pula mahasiswa yang aktif dan sangat berminat dengan materi mata kuliah pedagogic. Hal ini lebih disebabkan karena mereka memang benar-benar berniat untuk belajar, serta mereka sangat menyukai materi ke-pedagogik-an. (Untuk lebih jelasnya, terlampir nilai mata kuliah pedagogic mahasiswa program studi PGSD angkatan 2011/2012.)

Atas dasar kondisi lingkungan jurusan dan dosen serta karakteristik yang dimiliki kelas program studi PGSD angkatan
2011, maka mendorong peneliti untuk menjadikan kelas tersebut sebagai tempat penelitian.

3. Deskripsi Pelaksanaan Penerapan Model Pembelajaran Kooperatif

Pada Mata Kuliah Pedagogik

Untuk lebih jelasnya mengenai penerapan model pembelajaran kooperatif, maka bisa dideskripsikan dalam pembelajaran mata kuliah pedagogic sebagai berikut:

a. Perencanaan

Penerapan model pembelajaran kooperatif pada mata kuliah pedagogik ini dilaksanakan pada tanggal 16 Nopember 2012. Sebelumnya dosen melakukan berbagai persiapan diantaranya menyusun rencana kegiatan yang akan dikembangkan dalam kegiatan belajar mengajar. Penyusunan rencana kegiatan ini meliputi pembuatan satuan pelajaran (SAP), rencana pengajaran, menentukan model pembelajaran dan menyusun format observasi.

Hasil yang diharapkan dari pertemuan tersebut adalah semua mahasiswa dapat berperan aktif dalam pembelajaran, seperti bertanya, menjawab pertanyaan dan mengemukakan pendapat yang berkaitan dengan materi 
Edutech, Tahun 14, Vol.1, No.1, Februari 2015

perkuliahan mata kuliah pedagogic saat itu. Selain itu, mahasiswa diharapkan dapat berfikir kritis, mampu menemukan masalahmasalah sosial yang ada di lingkungan tempat tinggalnya dan mampu menemukan solusi pemecahan dari masalah yang dihadapinya.

Dalam pelaksanaan kegiatan belajar mengajar tersebut, peneliti menggunakan model pembelajaran kooperatif yang dikolaborasikan dengan metode ceramah serta tanya jawab. Untuk mengetahui hasil yang dicapai, maka peneliti menggunakan alat pengumpul data yang berupa panduan observasi dan/atau catatan lapangan, catatan mahasiswa yang berisi tentang pendapat mahasiswa terhadap proses belajar mengajar pada pertemuan tersebut dan hasil tugas kelompok mahasiswa.

b. Kegiatan Tindakan

1) Kegiatan Pembukaan (set induction)

Dosen memasuki ruangan kelas, kemudian mengucapkan salam. Setelah itu, dosen mengisi agenda kelas dan mengecek kehadiran mahasiswa dengan memanggil nama mahasiswa satu persatu. Mahasiswa yang hadir pada pertemuan tersebut sebanyak 43 (empat puluh tiga) orang, satu orang mahasiswa tidak hadir karena sakit. Sebelum memasuki kegiatan inti, dosen memberikan motivasi kepada mahasiswa dengan menyatakan bahwa kelas program studi PGSD angkatan 2011 adalah kelas yang berprestasi, mahasiswa-mahasiswanya memiliki potensi yang bagus untuk terlibat aktif dalam kegiatan belajar mengajar. Dosen juga memotivasi mahasiswa dengan menegaskan bahwa mahasiswa yang aktif akan mendapat point/nilai tambahan.

2) Kegiatan Inti (main point)

Dosen mengawali pembelajaran dengan menginformasikan kepada mahasiswa topik yang akan dipelajari atau dibahas pada pertemuan tersebut yaitu mengenai All about Paedagogic. Agar topik dapat digunakan sebagai sarana membentuk kerangka berfikir kritis mahasiswa serta untuk menarik perhatian dan semangat belajar mahasiswa, selanjutnya dosen mengembangkan dan menuliskan topik tersebut menjadi beberapa tema dalam pembelajaran 
Edutech, Tahun 14, Vol.1, No.1, Februari 2015

kooperatif. Tema tersebut

maka dosen membaginya

diantaranya :

1. Konsep Dasar Pedagogik

2. Pedagogik Sebagai Ilmu Pengetahuan

3. Tujuan, Keharusan dan

Kemungkinan Pendidikan

4. Pendidik Dan Anak Didik

5. Perkembangan Anak

Didik

6. Konsep, Karakteristik Dan

Alat Pendidikan

7. Lingkungan Pendidikan

Langkah berikutnya adalah dosen menyampaikan tujuan dari pembelajaran pada pertemuan hari itu. Kemudian secara demokratis dosen meminta pendapat mahasiswa tentang konsep besar atau judul yang dituliskan di papan tulis, kemudian memberikan kesempatan kepada mahasiswa untuk mengajukan tema yang disukainya dengan mengacu pada topik/sub topik yang telah disebutkan diatas. Setelah mendapat kesepakatan dari mahasiswa, selanjutnya dosen membagi mahasiswa ke dalam kelompok-kelompok kecil yang tediri atas enam sampai tujuh orang untuk setiap kelompoknya. Pada hari itu jumlah mahasiswa yang hadir adalah 43 orang, menjadi tujuh kelompok yang terdiri dari enam kelompok beranggotakan enam orang dan satu kelompok beranggotakan tujuh orang. Pembagian anggota kelompok diserahkan kepada mahasiswa sendiri untuk membaginya secara rata dan adil.

Setelah semua mahasiswa terbagi ke dalam kelompokkelompoknya, kemudian secara aklamasi dosen membagi tiap kelompok tema-tema yang sudah disiapkan dosen sebelumnya. Sebelum mahasiswa bekerja dalam kelompoknya, terlebih dahulu dosen memberikan arahan kepada mahasiswa tentang apa saja yang harus mereka lakukan dan kerjakan dalam kelompoknya.

Lalu dosen menginformasikan kepada seluruh mahasiswa bahwa tugas dari tiap kelompok adalah mengkaji dan memahami setiap tema yang telah diberikan kepada mereka serta mengisi lembar kerja mahasiswa yang ada disetiap akhir sub topic yang terdapat pada buku pegangan mahasiswa.

Saat mahasiswa belajar di dalam kelompok kecilnya maka 
Edutech, Tahun 14, Vol.1, No.1, Februari 2015

kegiatan dosen adalah mengawasi, mengontrol serta memberikan bimbingan kepada setiap kelompok kecil yang didatanginya terhadap tema materi yang sedang mereka kaji bersama. Adapun waktu yang diberikan dosen kepada mahasiswa untuk bekerja di dalam kelompoknya adalah 50 menit dari 2 sks dalam setiap pertemuan. Sedangkan waktu sisanya, yaitu 50 menit lagi digunakan untuk presentasi kelompok.

Selain membimbing, dosen pun memberikan penilaian kepada mahasiswa saat mereka bekerja di dalam kelompoknya. Penilaiannya adalah berupa nilai individu dan nilai kelompok. Setelah waktu yang telah ditentukan untuk diskusi dalam kelompok habis, maka dosen pun memberikan kesempatan kepada setiap kelompok untuk mempresentasikan hasil kajiannya kepada kelompok lain di depan kelas. Setiap kelompok berhak mengajukan pertanyaan atau pun memberikan jawaban serta sanggahan terhadap materi atau tema yang sedang dipresentasikan oleh kelompok lain.
3) Kegiatan Penutup

Dosen membuat kesimpulan terhadap materi yang telah dibahas dan didiskusikan. Setelah itu, membagikan lembar tugas kelompok berupa 4 (empat) pertanyaan yang harus dikerjakan secara kelompok. Selanjutnya, dosen meminta mahasiswa untuk menuliskan apa yang dirasakannya selama proses belajar mengajar berlangsung. Dosen menutup pembelajaran dengan salam dan tidak lupa memberikan reward berupa ungkapan terima kasih kepada seluruh mahasiswa karena mereka sudah mengikuti pembelajaran mata kuliah pedagogic pada hari itu dengan baik.

4. Penerapan Model Pembelajaran Kooperatif Pada Mata Kuliah Pedagogik

Berdasarkan hasil yang dicapai melalui penerapan model pembelajaran kooperatif pada mata kuliah pedagogik, maka diketahui telah terjadi peningkatan kemampuan mahasiswa dalam proses pembelajaran. Secara umum pada awal pembelajaran mata kuliah pedagogik menunjukkan suatu pembelajaran yang belum terfokus pada pembelajaran yang diharapkan 
Edutech, Tahun 14, Vol.1, No.1, Februari 2015

oleh dosen. Dosen menjelaskan materi, sedangkan mahasiswa masih banyak yang kurang focus memperhatikan apa yang sedang disampaikan oleh dosen. Aktivitas mahasiswa saat berada dalam kelas, hanya duduk dan mendengarkan saja. Tidak begitu banyak mahasiswa yang bertanya atau pun memberikan pendapatnya terhadap materi yang tengah dikaji saat itu. Bahkan ada saja mahasiswa yang asyik mengobrol dengan teman di sampingnya, atau bahkan ada mahasiswa yang sibuk dengan hpnya. Situasi ini bisa jadi karena mahasiswa bosan dan jenuh mendengarkan. Mungkin karena metode pembelajaran yang digunakan oleh dosen masih konvensional, yaitu metode ceramah dan tanya jawab. Hal ini tentu saja membuat mahasiswa sedikit enggan untuk menyimak pembelajaran. Dampak dari kondisi tersebut adalah tujuan pembejaran yang diharapkan dosen akhirnya tidak dapat tercapai dengan baik. Hingga dosen harus berusaha keras untuk menarik minat mahasiswa untuk mau mendengarkan penjelasan dari materi yang sedang mereka sampaikan.

Adapun saat dosen menggunakan metode pembelajaran dengan diskusi kelompok, hal ini kurang efektif. Dosen hanya baru sebatas mengelompokkan mahasiswa ke dalam beberapa kelompok. Namun pada aplikasinya, dalam kegiatan pembelajaran tetap belum terlaksana dengan baik. Begitu pula dengan aktivitas belajar mahasiswa, diawali dengan respon yang kurang positif. Namun, seiring dengan pelaksanaan tindakan dari satu pertemuan ke pertemuan berikutnya, pada akhirnya menunjukkan adanya peningkatan atau kemajuan secara kualitatif dan kuantitatif.

Pada pertemuan selanjutnya, peningkatan terhadap aktivitas mengajar dosen, aktivitas belajar mahasiswa, dan proses belajar mengajar terlihat semakin meningkat setelah mencoba untuk menerapkan model pembelajaran kooperatif dalam mata kuliah pedagogik. Peningkatan tersebut dapat dilihat, baik secara kualitatif maupun kuantitatif. Dalam hal ini dosen sudah mulai terbiasa dalam menampilkan topik dari kurikulum dan kemudian menghubungkannya dengan materi yang akan dibahas pada pertemuan saat itu. Dosen sudah mempersiapkan settingan yang disesuaikan dengan metode pembelajaran yang sedang diterapkan sematang mungkin, agar dalam proses pembelajaran di kelas mahasiswa bisa belajar dengan nyaman dan maksimal dalam menampilkan setiap kemampuannya, 
Edutech, Tahun 14, Vol.1, No.1, Februari 2015

sekali pun dihadapan rekan-rekan sekelasnya. Aktivitas mahasiswa pun cenderung meningkat. Hal ini terbukti dengan semakin banyaknya mahasiswa yang mulai tertarik belajar dengan penerapan metode pembelajaraan kooperatif tersebut.

Bahkan di sini terlihat setiap anggota kelompok mulai bersaing untuk mengetahui siapa yang lebih bagus dalam mempresentasikan tema yang menjadi kajian kelompoknya. Mahasiswa bersaing ketat untuk itu. Bukan hanya terjadi persaingan diantara sesama anggota dalam satu kelompok saja, tetapi antar kelompok pun berusaha saling bersaing secara positif untuk mendapatkan poin kelompok sebanyak-banyaknya. Dari sinilah muncul kesadaran dalam diri siswa bahwa keberhasilan kelompok tergantung dari sebaik apa kerja sama diantara sesama anggota kelompoknya.

Kegiatan pembelajaran dengan model pembelajaran kooperatif semakin memudahkan kinerja dosen di kelas untuk menyampaikan tujuan pembelajaran dari setiap pertemuan. Pembahasan materi yang berupa fakta dikaji secara garis besar. Kemudian dikembangkan oleh mahasiswa sendiri dari hasil pemikiran dan penemuan mereka dari berbagai sumber, termasuk dari hasil diskusi dengan sesama anggota tim. Dan ini sebagai pembelajaran mahasiswa untuk bisa berekspresi dan mengeksplor pemahaman dan kemampuan yang ada pada diri masing-masing mahasiswa.

Semua peningkatan secara kuantitatif ini menunjukkan adanya kondisi yang semakin baik dalam proses pembelajaran mata kuliah pedagogic di kelas program studi PGSD angkatan 2011 . Peningkatan yang terjadi dalam setiap pertemuan ini semakin diperkuat dengan adanya data yang diperoleh dari angket respon tentang apa yang mereka rasakan selama mengikuti pembelajaran melalui penerapan model pembelajaran kooperatif pada mata kuliah pedagogik. Untuk lebih jelasnya dapat dilihat pada tabel dan grafik di bawah ini: 
Tabel 1

Angket Respon Mahasiswa Terhadap Penerapan Model Pembelajaran Kooperatif pada Mata Kuliah Pedagogik

\begin{tabular}{|l|l|c|c|}
\hline No & \multicolumn{1}{|c|}{ Indikator } & Metode Ceramah & $\begin{array}{c}\text { Metode } \\
\text { Pembelajaran } \\
\text { Kooperatif }\end{array}$ \\
\hline 1 & $\begin{array}{l}\text { Saya bersemangat mengikuti mata } \\
\text { kuliah }\end{array}$ & 25 & 38 \\
\hline 2 & Saya aktif bertanya & 5 & 9 \\
\hline 3 & Saya aktif berpendapat & 7 & 30 \\
\hline 4 & $\begin{array}{l}\text { Saya merasa mudah memahami } \\
\text { materi mata kuliah }\end{array}$ & 15 & 38 \\
\hline 5 & $\begin{array}{l}\text { Saya merasa mata kuliah pedagogik } \\
\text { menarik }\end{array}$ & 20 & 35 \\
\hline 6 & $\begin{array}{l}\text { Saya merasa mata kuliah pedagogic } \\
\text { menyenangkan }\end{array}$ & 21 & 24 \\
\hline 7 & $\begin{array}{l}\text { Saya merasa mudah untuk membuat } \\
\text { kesimpulan dari materi yang telah } \\
\text { dipelajari }\end{array}$ & 18 & \\
\hline
\end{tabular}

Untuk lebih jelasnya dapat dilihat pada gambar grafik 1 di bawah ini.

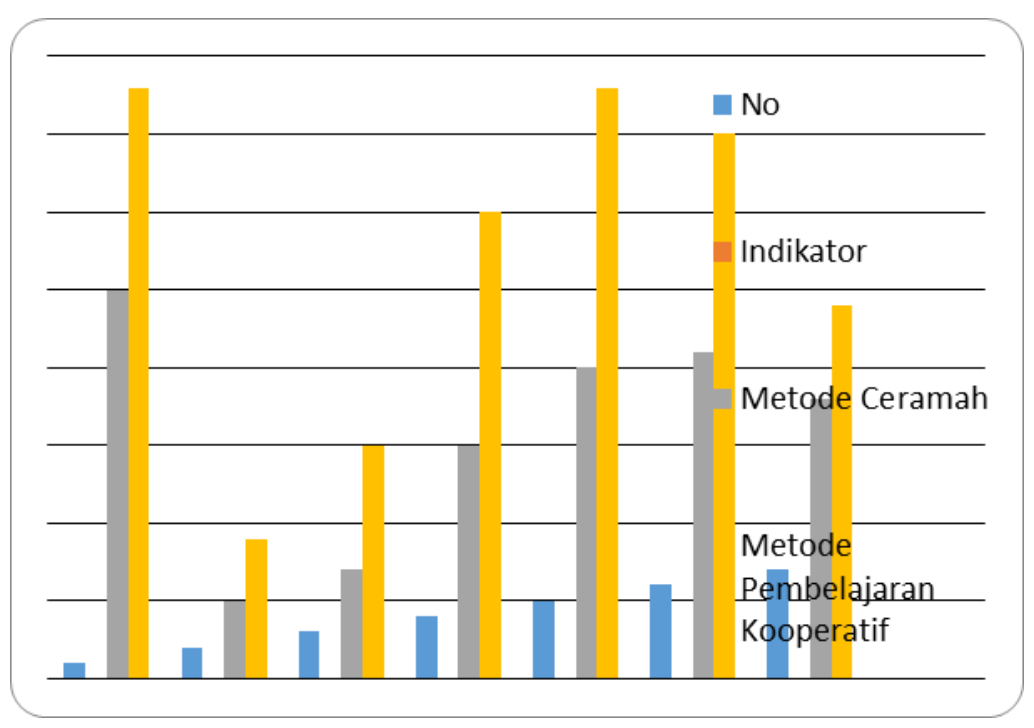

Grafik 1

Angket Respon Mahasiswa Terhadap Penerapan Model Pembelajaran Kooperatif pada Mata Kuliah Pedagogik 
5. Kelebihan Dan Kelemahan Model Pembelajaran Kooperatif Pada Mata Kuliah Pedagogik

Tabel 2

Kelebihan dan Kelemahan Metode Pembelajaran Kooperatif

\begin{tabular}{|c|c|c|}
\hline No & Kelebihan & Kelemahan \\
\hline 1 & $\begin{array}{l}\text { Dapat melibatkan peserta didik secara aktif } \\
\text { dalam mengembangkan pengetahuan, sikap, } \\
\text { dan keterampilannya dalam suasana belajar } \\
\text { mengajar yang bersifat terbuka dan } \\
\text { demokratis. }\end{array}$ & $\begin{array}{l}\text { Bisa menjadi tempat mengobrol } \\
\text { atau gosip }\end{array}$ \\
\hline 2 & $\begin{array}{l}\text { Dapat mengembangkan aktualisasi berbagai } \\
\text { potensi diri yang telah dimiliki oleh peserta } \\
\text { didik. }\end{array}$ & $\begin{array}{l}\text { Kelemahan yang senantiasa terjadi } \\
\text { dalam pembelajaran kooperatif } \\
\text { adalah dapat menjadi tempat } \\
\text { mengobrol. Hal ini terjadi jika } \\
\text { anggota kelompok tidak } \\
\text { mempunyai kedisiplinan dalam } \\
\text { belajar, seperti datang terlambat, } \\
\text { mengobrol atau bergosip membuat } \\
\text { waktu berlalu begitu saja sehingga } \\
\text { tujuan untuk belajar menjadi sia- } \\
\text { sia. }\end{array}$ \\
\hline 3 & $\begin{array}{l}\text { Dapat mengembangkan dan melatih } \\
\text { berbagai sikap, nilai, dan keterampilan- } \\
\text { keterampilan sosial untuk diterapkan dalam } \\
\text { kehidupan di masyarakat. }\end{array}$ & $\begin{array}{l}\text { Sering terjadi debat sepele di } \\
\text { dalam kelompok }\end{array}$ \\
\hline 4 & $\begin{array}{l}\text { Peserta didik tidak hanya sebagai obyek } \\
\text { belajar melainkan juga sebagai subyek } \\
\text { belajar karena peserta didik dapat menjadi } \\
\text { tutor sebaya bagi peserta didik lainnya. }\end{array}$ & \\
\hline 5 & $\begin{array}{l}\text { Peserta didik dilatih untuk bekerjasama, } \\
\text { karena bukan materi saja yang dipelajari } \\
\text { tetapi juga tuntutan untuk mengembangkan } \\
\text { potensi dirinya secara optimal bagi } \\
\text { kesuksesan kelompoknya. }\end{array}$ & \\
\hline 6 & $\begin{array}{l}\text { Memberi kesempatan kepada peserta didik } \\
\text { untuk belajar memperoleh dan memahami } \\
\text { pengetahuan yang dibutuhkan secara } \\
\text { langsung, sehingga apa yang dipelajarinya } \\
\text { lebih bermakna bagi dirinya. }\end{array}$ & \\
\hline
\end{tabular}

Sumber: Analisis peneliti, 2012

\section{KESIMPULAN DAN SARAN}

Berdasarkan hasil penelitian yang telah dilakukan kepada sasaran penelitian, dan dari hasil pembahasan tentang penerapan metode pembelajaran kooperatif maka dapat disimpulkan beberapa hal sebagai berikut :

1. Berdasarkan hasil pengamatan dan pengalaman peneliti selama mengajar mata kuliah pedagogik, kondisi awal karakteristik 
Edutech, Tahun 14, Vol.1, No.1, Februari 2015

kemampuan mahasiswa PGSD pada mata kuliah pedagogik di kelas program studi PGSD angkatan 2011 ini pada dasarnya memiliki kualitas yang cukup baik dalam setiap mata kuliah, tetapi secara umum memiliki kesan cukup negatif terhadap beberapa mata kuliah. Pada awal masuk di semester pertama dan kedua saat pembelajaran pedagogik berlangsung, peneliti menyaksikan bahwa suasana belajar kurang menyenangkan, motivasi belajar mahasiswa rendah, dan rata-rata mahasiswa masih pasif, kurang aktif dalam menyimak ataupun bertanya jawab saat proses pembelajaran berlangsung.

2. Dalam pelaksanaan penerapan model pembelajaran kooperatif pada mata kuliah pedagogik, peneliti melakukan langkah-langkah pembelajaran sebagai berikut : a) pendidik merancang pembelajaran, mempertimbangkan dan menetapkan target pembelajaran yang ingin dicapai, b) merancang lembar observasi kegiatan peserta didik dalam belajar secara bersama-sama dalam kelompok-kelompok kecil, c) mengarahkan dan membimbing peserta didik baik secara individu maupun kelompok, dan d) memberikan kesempatan kepada peserta didik untuk mempersentasekan hasil kerjanya.

3. Kelebihan dalam penerapan model pembelajaran kooperatif antara lain :

a Dapat melibatkan peserta didik secara aktif dalam mengembangkan pengetahuan, sikap, dan keterampilannya dalam suasana belajar mengajar yang bersifat terbuka dan demokratis.

b Dapat mengembangkan aktualisasi berbagai potensi diri yang telah dimiliki oleh peserta didik.

c Dapat mengembangkan dan melatih berbagai sikap, nilai, dan keterampilan-keterampilan sosial untuk diterapkan dalam kehidupan di masyarakat.

d Peserta didik tidak hanya sebagai obyek belajar melainkan juga sebagai subyek belajar karena peserta didik dapat menjadi tutor sebaya bagi peserta didik lainnya.

e Peserta didik dilatih untuk bekerjasama, karena bukan materi saja yang dipelajari tetapi juga tuntutan untuk mengembangkan potensi dirinya secara optimal bagi kesuksesan kelompoknya.

f Memberi kesempatan kepada peserta didik untuk belajar 
Edutech, Tahun 14, Vol.1, No.1, Februari 2015

memperoleh dan memahami

pengetahuan yang dibutuhkan

secara langsung, sehingga apa

yang dipelajarinya lebih

bermakna bagi dirinya.

Adapun kelemahan dalam penerapan

model pembelajaran kooperatif

antara lain :

a.Bisa menjadi tempat mengobrol atau gossip

b. Sering terjadi debat sepele di dalam kelompok

c.Bisa terjadi kesalahan kelompok

\section{DAFTAR PUSTAKA}

Hasan, Said Hamid. (2000). Kurikulum dan Buku Teks Sejarah. Historia: Jurnal Pendidikan Sejarah. I, (1), 13-38.

Hopkins, D. (1993). A Theacher's Guid to Classroom Research. Philadelphia: Open University Press.

Kagan, S. (2013). Cooperative Learning Structures. Retrieved from http://www.kaganonline.com/online _magazine/spencers_thinkpad.php

Kardiawarman, dkk. (2000). Dasar-Dasar Proses Belajar Mengajar. Bandung: PT. Sinar Baru Algesindo.

Lie, Anita. (2004). Cooperative Learning. Mempraktikkan Cooperative Learning di Ruang-Ruang Kelas. Jakarta: PT.Gramedia.

Maleong, J. Lexy. (2002). Metodologi Penelitian Kualitatif. Bandung: Remaja Rosdakarya.

Rianto, Y. (1996). Metodologi Penelitian Pendidikan serta Tinjauan Dasar. Surabaya: SIC.

Slavin, Robert. E (2009). Cooperative Learning. Teori, Riset dan Praktik. Bandung: Nusa Media

Sumaatmadja, Nursid. (1981). Metodologi Pengajaran Ilmu Pengetahuan
Sosial (IPS). Bandung: Alumni Bandung.

Sudjana, Nana dan Ibrahim. (2001). Penelitian dan Penilaian Pendidikan. Bandung: Sinar Baru Algesindo.

Sukardi. (2003). Metodologi Penelitian Pendidikan: Kompetensi dan Praktiknya. Jakarta: PT. Bumi Aksara.

Suryo, Djoko. (1990). Menjadi Guru Profesional. Bandung: Rosdakarya.

(2004). Pedoman Pembelajaran secara Konstektual. Lembaga Penjamin Mutu Pendidikan Jawa Barat. 